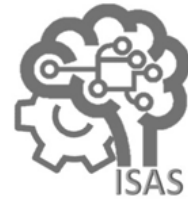

JOURNAL OF APPLIED CIVIL ENGINEERING AND INFRASTRUCTURE TECHNOLOGY (JACEIT)

Vol. 2 No. 2 (2021) 7-13

ISSN Media Elektronik: 2723-5378

\title{
Pengaruh Penambahan Limbah Plastik Low Density Polyethylene Terhadap Karakteristik Campuran Laston AC-WC
}

\author{
Erni Dwi Susanti ${ }^{1}$, Mirza Ghulam Rifqi ${ }^{2}$, M. Shofi'ul Amin ${ }^{3}$ \\ 1,2,3 Jurusan Teknik Sipil, Politeknik Negeri Banyuwangi \\ 1emai1 : ernids892@gmail.com*, ${ }^{2}$ email : mirza@poliwangi.ac*, ${ }^{3}$ email : shofiul@ poliwangi.ac.id
}

\begin{abstract}
The problem of plastic waste is now one of the world's concentrations. Efforts to reduce and prevent many have been done, but in general the results obtained are not comparable with the growing use of plastics that continues to increase, especially plastics that are not managed properly. One of the efforts made is the utilization of plastic waste as added ingredients of Laston AC-WC hot asphalt mixture called modification. The purpose of this study was to determine how the effect of adding Low Density Polyethylene (LDPE) plastic waste to the characteristics of Marshall Laston AC-WC. Tests carried out include aggregate testing, asphalt testing, and plastic testing, and Marshall testing. The design of the mixture is done by dry (dry process) using a variation of plastic content of $0 \%$, $4.5 \%, 5 \%$, and $5.5 \%$, each of which uses 5 levels of asphalt which is 5\%, 5.5\%, 6\%, 6.5\%, and 7\% with 3 specimens each, so that there are a total of 75 specimens. Marshall test results obtained KAO of $6.5 \%$ with a variation of plastic content of 5.5\%, obtained stability of $2167.40 \mathrm{~kg}$, Flow $3.8 \mathrm{~mm}$, VIM 3.94\%, VMA $15.95 \%$, VFA / VFB 77, 12\%, and MQ $570.37 \mathrm{~kg} / \mathrm{mm}$. So that the addition of LDPE type plastic waste meets (General Specifications of Bina Marga, 2018).
\end{abstract}

Keywords: Laston AC-WC, LDPE plastic, Marshall, dry process, KAO.

\begin{abstract}
Abstrak
Permasalahan sampah plastik saat ini telah menjadi salah satu konsentrasi dunia. Upaya pengurangan dan pencegahan telah banyak dilakukan, namun secara umum hasil yang didapat tidak sebanding dengan pertumbuhan penggunaan plastik yang terus meningkat khususnya plastik yang tidak terkelola dengan baik. Salah satu upaya yang dilakukan adalah pemanfaatan limbah plastik sebagai bahan tambah campuran beraspal panas Laston ACWC yang disebut modifikasi. Tujuan penelitian ini adalah untuk mengetahui bagaimana pengaruh penambahan limbah plastik jenis Low Density Polyethylene (LDPE) terhadap karakteristik Marshall Laston AC-WC. Pengujian yang dilakukan antara lain pengujian agregat, pengujian aspal, pengujian plastik, dan pengujian Marshall. Perancangan campuran dilakukan dengan cara kering (dry process) menggunakan variasi kadar plastik sebesar $0 \%, 4,5 \%, 5 \%$, dan 5,5\% yang masing-masing memakai 5 kadar aspal yaitu 5\%, 5,5\%, 6\%, 6,5\%, dan 7\% dengan masing-masing 3 benda uji, sehingga total ada 75 benda uji. Hasil uji Marshall diperoleh KAO sebesear 6,5\% dengan variasi kadar plastik sebesar 5,5\%, diperoleh stabilitas 2167,40 kg, Flow 3,8 mm, VIM 3,94\%, VMA $15,95 \%$, VFA/VFB 77,12\%, dan MQ 570,37 kg/mm. Sehingga penambahan limbah plastik jenis LDPE memenuhi (Spesifikasi Umum Bina Marga, 2018).
\end{abstract}

Kata kunci: Laston AC-WC, Plastik LDPE, Marshall, Cara Kering, KAO.

Diterima Redaksi : 04-08-2020 | Selesai Revisi : 21-09-2021 | Diterbitkan Online : 01-12-2021

\section{Pendahuluan}

Plastik banyak dipakai dalam kehidupan sehari-hari, karena mempunyai keunggulan-keunggulan seperti kuat, ringan dan stabil. Komposisi sampah plastik di
Indonesia sebesar 65 juta ton yang diproduksi setiap hari, 15 juta ton mengotori ekosistem, $7 \%$ sampah didaur ulang, dan 69\% sampah berakhir di Tempat Pembuangan Akhir (TPA). Sedangkan sampah plastik 
terdapat $14 \%$ yang artinya ada 1.3 juta sampah plastik per tahun yang tidak dikelola [6].

Sebagai upaya dalam mengatasi sampah plastik yang belum terkelola dengan baik khususnya limbah botol yang dapat ditekan seperti botol make up, facial wash, dsb yang merupakan salah satu jenis plastik Low Density Polyethylene (LDPE), dilakukan pengolahan limbah plastik sebagai bahan tambah campuran beraspal panas yang disebut modifikasi. Salah satu bahan tambah yang umum digunakan adalah polimer, plastik mengandung polimer yang bersifat [2].

Menurut [4] bahan polimer dapat meningkatkan kekakuan aspal melalui peningkatan nilai stabilitasnya. Pada penelitian (Siregar, 2019) menunjukkan kualitas campuran aspal optimum pada kadar plastik LDPE 6\%. Hal ini dikarenakan plastik cair ketika dicampurkan dengan agregat, plastik menempel cepat dan mengikat agregat sehingga memperkecil aspal yang masuk ke pori-pori agregat dibandingkan aspal tanpa bahan tambah plastik.

Berdasarkan uraian diatas, peneliti akan menggunakan jenis sampah plastik Low Density Polyethylene (LDPE) sebagai bahan tambah campuran beraspal sebagai modifikasi yang diharapkan dapat meningkatkan karakteristik campuran Lapis Aspal Beton (Laston) ACWC (Asphalt Concrete - Wearing Course) yang merupakan lapis perkerasan terletak paling atas dan berfungsi sebagai lapisan aus dalam kemampuannya untuk menerima beban lalu lintas.

\section{Metode Penelitian}

Penelitan dilaksanakan di Laboratorium Uji Bahan Jalan Teknik Sipil Politeknik Negeri Banyuwangi. Sumber material agregat kasar dan agregat halus berasal dari AMP Argotuhu Tegalsari, Banyuwangi serta material aspal keras Pertamina penetrasi 60/70 diperoleh dari Laboratorium setempat. Pelaksanaan pengujian material agregat dan aspal berdasarkan pedoman Spesifikasi Umum Bina Marga tahun 2018. Berikut merupakan gambaran langkah kerja atau flow chart penelitian dapat dilihat pada Gambar 1.

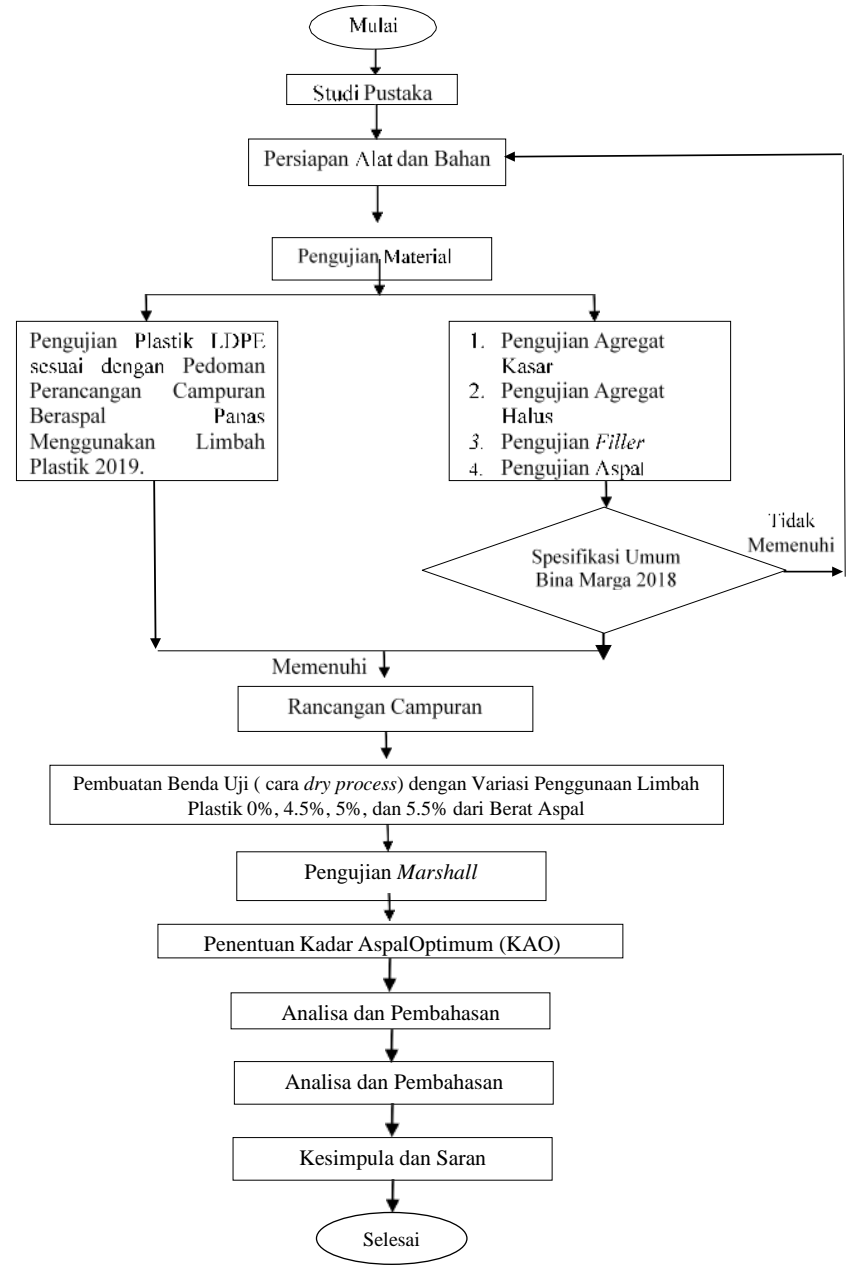

Gambar 1. Flow Chart Penelitian

\subsection{Studi Literatur}

Studi literatur yang dimaksud adalah mencari literaturliteratur yang berhubungan dengan pelaksanaan pengerjaan penelitian. Studi literatur dilakukan agar tidak terjadi kesalahan yang signifikan dalam pelaksanaan penelitian.

\subsection{Persiapan Alat dan Bahan}

Alat dan bahan disiapkan terlebih dahulu sebelum melakukan pengujian material atau pembuatan benda uji.

\subsection{Pengujian Bahan dan Material}

Pengujian material digunakan untuk mengetahui karakteristik material. Selain itu juga untuk mengetahui studi layak dan tidak layak sebuah material sesuai dengan standar yang berlaku.

\subsection{Rancangan Campuran}

Tahap kali ini ialah perencanaan campuran aspal, dengan menggunakan gradasi campuran laston ACWC. Untuk proporsi 1 briket aspal dengan kadar aspal $\mathrm{Pb} \%, \mathrm{~Pb}+0,5 \%, \mathrm{~Pb}+1 \%, \mathrm{~Pb}-0,5 \%, \mathrm{~Pb}-1 \%$. 
Selanjutnya proporsi kadar plastik yang digunakan terdapat 6 parameter yang harus dipenuhi, yaitu yaitu $0 \%, 4.5 \%, 5 \%$, dan $5.5 \%$.

\subsection{Pembuatan Benda Uji}

Pembuatan benda uji sesuai rancangan campuran dari hasil yang telah direncanakan dengan 3.3. Hasil Uji Marshall Campuran Plastik 0\% penambahan kadar limbah plastik LDPE sebesar 0\%, $4.5 \%, 5 \%$, dan $5.5 \%$ dari berat aspal total.

\subsection{Pengujian Marshall}

Setelah pembuatan benda uji, akan dilakukan pengujian benda uji dengan alat Marshall. Pengujian dilakukan setelah benda uji melalui proses perendaman selama 24 jam dan selanjutnya perendaman didalam water bath dengan suhu $60^{\circ} \mathrm{C}$ selama 30 menit. Dari hasil pengujian dengan menggunakan alat Marshall, maka didapatkan parameter-parameter sifat campuran yang disyaratkan yaitu stabilitas, flow, VIM, VMA, dan VFA.

\subsection{Penentuan Kadar Aspal Optimum (KAO)}

Setelah melakukan pengujian benda uji dengan menggunakan alat Marshall, maka telah diketahui semua hasil pengujian beserta parameter sifat campuran masing-masing variasi kadar plastik dengan kadar aspal yang berbeda. Maka dapat ditentukan yang mana dari keempat variasi kadar plastik yang memiliki hasil paling optimum atau yang mendekati sesuai ketentuan dan disitulah dapat diperoleh salah satu variasi kadar plastik dengan kadar aspal yang disebut Kadar Aspal Optimum dibandingkan dengan variasi kadar yang lainnya.

\section{Hasil dan Pembahasan}

Berikut merupakan hasil pengolahan data yang diperoleh melalui penelitian yang telah dilakukan.

\subsection{Pengujian Material Agregat dan Filler}

Pada campuran Laston AC-WC yang merupakan aspal normal tanpa penambahan kadar plastik LDPE atau plastik sebesar $0 \%$ dengan menggunakan 5 variasi kadar aspal yaitu 5\%, 5,5\%, 6\%, 6,5\%, dan 7\% didapatkan hasil pengujian Marshall berikut pada Tabel 1.

\begin{tabular}{ccccccc}
\multicolumn{7}{c}{ Tabel 1. Hasil Uji Marshall Plastik 0\% } \\
\hline Macam & VIM & FLOW & Stabilitas & MQ & VMA & VFB \\
\cline { 2 - 7 } Campuran & $\%$ & $\mathrm{~mm}$ & $\mathrm{~kg}$ & $\begin{array}{c}\mathrm{Kg} / \\
\mathrm{mm}\end{array}$ & $\%$ & $\%$ \\
\hline $5,0 \%$ & 9.54 & 3.2 & 1267.1 & 396.0 & 18.61 & 396.0 \\
\hline $5,5 \%$ & 8.47 & 3.5 & 1356.4 & 387.5 & 18.78 & 387.5 \\
\hline $6,0 \%$ & 4.95 & 3.5 & 1380.7 & 394.5 & 17.30 & 394.5 \\
\hline $6,5 \%$ & 4.80 & 2.7 & 1440.8 & 533.6 & 17.30 & 533.6 \\
\hline $7,0 \%$ & 5.99 & 3.6 & 1568.2 & 435.6 & 19.84 & 435.6 \\
\hline Spesifikasi & $3-5$ & $2-4$ & $>900$ & Min. 250 & $>15$ & $>65$ \\
Umum BM & & & & & & \\
\hline
\end{tabular}

Tabel 2. Hasil Uji Marshall Plastik 4,5\%

\begin{tabular}{ccccccc}
\hline Macam & VIM & FLOW & Stabilitas & MQ & VMA & VFB \\
\cline { 2 - 7 } Campuran & $\%$ & $\mathrm{~mm}$ & $\mathrm{~kg}$ & $\begin{array}{c}\mathrm{Kg} / \\
\mathrm{mm}\end{array}$ & $\%$ & $\%$ \\
\hline $5,0 \%$ & 7.93 & 3.7 & 1544.9 & 417.5 & 17.16 & 53.79 \\
\hline $5,5 \%$ & 7.91 & 3.9 & 1578.3 & 404.7 & 18.29 & 56.75 \\
\hline $6,0 \%$ & 4.93 & 3.8 & 1715.4 & 451.7 & 16.67 & 70.45 \\
\hline $6,5 \%$ & 4.72 & 2.9 & 1715.4 & 591.5 & 16.67 & 73.45 \\
\hline $7,0 \%$ & 5.80 & 3.7 & 1663.5 & 449.6 & 19.68 & 74.23 \\
\hline Spesifikasi & $3-5$ & $2-4$ & $>900$ & Min. 250 & $>15$ & $>65$ \\
Umum BM & & & & & & \\
\hline
\end{tabular}

Pengujian yang dilakukan pada material agregat kasar Berdasarkan hasil pengujian pada Tabel 1, didapatkan meliputi analisa saringan, berat jenis, ketahanan agregat nilai stabilitas tertinggi pada kadar aspal $7 \%$ yaitu (Impact Test), Keausan agregat dengan mesin Los 1568,2 kg. Nilai Flow tertinggi terdapat pada variasi Angeles, uji agregat kasar lolos ayakan no.200. Pada kadar aspal sebesar 7\% yaitu 3,6 mm dan yang terendah material agregat halus dilakukan pengujian analisa pada variasi kadar aspal 6,5\% yaitu sebesar 2,7 mm. saringan, berat jenis, dan agregat lolos ayakan no.200. Hasil tersebut telah memenuhi Spesifikasi umum Bina Sedangkan pengujian material aspal meliputi berat jenis Marga tahun 2018. aspal, daktilitas, titik lembek, titik nyala dan titik bakar. Pengujian material yang dilakukan telah memenuhi Spesifikasi Umum Bina Marga 2018 yang merujuk pada SNI.

\subsection{Pengujian Marshall}

\subsection{Hasil Uji Marshall Plastik 4,5\%}

Pada campuran Laston AC-WC menggunakan kadar plastik 4,5\% dengan 5 variasi kadar aspal yaitu 5\%, $5,5 \%, 6 \%, 6,5 \%$, dan $7 \%$ didapatkan hasil pengujian berikut ini pada Tabel 2. Berdasarkan hasil pengujian Untuk memperoleh kadar aspal optimum (KAO) pada Tabel 2, nilai stabilitas tertinggi pada kadar aspal campuran lapis aspal beton (Laston) dalam penelitian ini $6 \%$ dan $6,5 \%$ yaitu $1715,4 \mathrm{~kg}$. Nilai Flow tertinggi digunakan kadar aspal 5 variasi kadar aspal yaitu 5\%, terdapat pada variasi kadar aspal sebesar 5,5\% yaitu 3,9 $5,5 \%, 6 \%, 6,5 \%$, dan $7 \%$ untuk campuran plastik LDPE $\mathrm{mm}$ dan yang terendah pada variasi kadar aspal $6,5 \%$ dengan variasi kadar 0\%, 4,5\%, 5\%, dan 5,5\%. yaitu sebesar 2,9 mm. Tetapi untuk nilai Flow pada Berdasarkan (Spesifikasi Umum Bina Marga, 2018), semua variasi kadar aspal telah memenuhi persyaratan

Journal of Applied Civil Engineering and Infrastructure (JACEIT) 
sesuai dengan (Spesifikasi Umum Bina Marga, 2018) 3.7 Rekapitulasi Pengujian Marshall yaitu pada rentang 2-4 $\mathrm{mm}$.

\subsection{Hasil Uji Marshall Plastik 5\%}

Penambahan kadar plastik LDPE atau plastik sebesar 5\% dengan menggunakan 5 variasi kadar aspal yaitu 5\%, $5,5 \%, 6 \%, 6,5 \%$, dan $7 \%$ didapatkan hasil pengujian Marshall berikut pada Tabel 3.

Tabel 3. Hasil uji Marshall Plastik 5\%

\begin{tabular}{ccccccc}
\hline \multirow{2}{*}{ Macam } & VIM & FLOW & Stabilitas & MQ & VMA & VFB \\
\cline { 2 - 7 } & $\%$ & $\mathrm{~mm}$ & $\mathrm{~kg}$ & $\begin{array}{c}\mathrm{Kg} / \\
\mathrm{mm}\end{array}$ & $\%$ & $\%$ \\
\hline $5,0 \%$ & 7.28 & 3.7 & 1633.9 & 441.6 & 16.58 & 56.06 \\
\hline $5,5 \%$ & 7.57 & 4.3 & 1696.8 & 394.6 & 17.99 & 57.93 \\
\hline $6,0 \%$ & 4.61 & 3.8 & 1715.4 & 451.4 & 16.40 & 71.89 \\
\hline $6,5 \%$ & 4.39 & 3.7 & 1759.8 & 475.6 & 16.40 & 75.17 \\
\hline $7,0 \%$ & 4.64 & 4.4 & 1800.6 & 409.2 & 18.68 & 75.17 \\
\hline Spesifikasi & $3-5$ & $2-4$ & $>900$ & Min. 250 & $>15$ & $>65$ \\
Umum BM & & & & & & \\
\hline
\end{tabular}

Tabel 4. Hasil uji Marshall Plastik 5.5\%

\begin{tabular}{ccccccc}
\hline \multirow{2}{*}{ Macam } & VIM & FLOW & Stabilitas & MQ & VMA & VFB \\
\cline { 2 - 7 } Campuran & $\%$ & $\mathrm{~mm}$ & $\mathrm{~kg}$ & $\begin{array}{c}\mathrm{Kg} / \\
\mathrm{mm}\end{array}$ & $\%$ & $\%$ \\
\hline $5,0 \%$ & 7.07 & 4.1 & 1722.78 & 420.20 & 16.38 & 56.85 \\
\hline $5,5 \%$ & 7.46 & 4.4 & 2026.59 & 460.59 & 17.89 & 58.32 \\
\hline $6,0 \%$ & 4.10 & 3.8 & 2048.82 & 539.16 & 15.95 & 74.31 \\
\hline $6,5 \%$ & 3.94 & 3.8 & 2167.37 & 570.37 & 15.95 & 77.12 \\
\hline $7,0 \%$ & 4.19 & 4.6 & 2304.45 & 500.98 & 18.29 & 77.12 \\
\hline Spesifikasi & $3-5$ & $2-4$ & $>900$ & Min. 250 & $>15$ & $>65$ \\
Umum BM & & & & & & \\
\hline Berdasarkan Tabel $3, \mathrm{didap}$ & & & & & & \\
\hline
\end{tabular}

Berdasarkan Tabel 3, didapatkan nilai stabilitas tertinggi pada kadar aspal $7 \%$ yaitu $1800,6 \mathrm{~kg}$ dan flow yang memenuhi persyaratan sesuai dengan (Spesifikasi Umum Bina Marga, 2018) yaitu kadar aspal 5\%, 6\%, dan $6,5 \%$ pada rentang $2-4 \mathrm{~mm}$.

\subsection{Hasil Uji Marshall Plastik 5,5\%}

Penambahan kadar plastik LDPE atau plastik sebesar 5\% dengan menggunakan 5 variasi kadar aspal yaitu 5\%, $5,5 \%, 6 \%, 6,5 \%$, dan 7\% didapatkan hasil pengujian Marshall berikut pada Tabel 4. Berdasarkan hasil pengujian pada Tabel 4, diperoleh nilai stabilitas tertinggi pada kadar aspal $7 \%$ yaitu $2304,45 \mathrm{~kg}$. Nilai stabilitas terus mengalami kenaikan dari kadar aspal kecil ke yang tertinggi. Nilai Flow yang memenuhi persyaratan sesuai dengan (Spesifikasi Umum Bina Marga, 2018) yaitu kadar aspal 6\% dan 6,5\% pada rentang 2-4 $\mathrm{mm}$.
Setelah didapatkan hasil pengujian masing-masing variasi kadar plastik dengan kelima variasi kadar aspal $(\mathrm{Pb})$, maka dilakukan perekapan nilai hasil pengujian masing-masing yang meliputi stabilitas, flow, VIM, VMA, VFA/VFB, dan MQ untuk memudahkan dalam penentuan Kadar Aspal Optimum (KAO). Berikut ini merupakan hasil rekap pengujian yang dapat dilihat pada Tabel 5.

Tabel 5. Rekapitulasi Pengujian Marshall

\begin{tabular}{|c|c|c|c|c|c|c|c|}
\hline Kadar Aspal & Kadar Plastik & Stabilitas & Flow & VIM & VMA & VFB & MQ \\
\hline \multirow{2}{*}{\multicolumn{2}{|c|}{ Spesifikasi Umum BM 2018}} & $>900$ & $2-4$ & $3-5$ & $>15$ & $>65$ & $>250$ \\
\hline & & $\mathrm{Kg}$ & $\mathrm{mm}$ & $\%$ & $\%$ & $\%$ & $\mathrm{Kg} / \mathrm{mm}$ \\
\hline \multirow[t]{4}{*}{$\mathrm{Pb} 5 \%$} & LDPE 0 \% & 1267.10 & 3.20 & 9.54 & 18.61 & 48.72 & 396 \\
\hline & LDPE $4.5 \%$ & 1544.90 & 3.7 & 7.93 & 17.16 & 53.79 & 417.54 \\
\hline & LDPE $5 \%$ & 1633.90 & 3.7 & 7.28 & 16.58 & 56.06 & 441.59 \\
\hline & LDPE $5.5 \%$ & 1722.80 & 4.1 & 7.07 & 16.38 & 56.85 & 420.2 \\
\hline \multirow[t]{4}{*}{$\mathrm{Pb} 5.5 \%$} & LDPE 0\% & 1356.39 & 3.5 & 8.47 & 18.78 & 54.93 & 387.5 \\
\hline & LDPE $4.5 \%$ & 1578.30 & 3.9 & 7.91 & 18.29 & 56.75 & 404.69 \\
\hline & LDPE $5 \%$ & 1696.80 & 4.3 & 7.57 & 17.99 & 57.93 & 394.6 \\
\hline & LDPE $5.5 \%$ & 2026.60 & 4.4 & 7.46 & 17.89 & 58.32 & 460.59 \\
\hline \multirow[t]{4}{*}{$\mathrm{Pb} 6 \%$} & LDPE $0 \%$ & 1380.67 & 3.5 & 4.95 & 17.3 & 69.96 & 394.5 \\
\hline & LDPE $4.5 \%$ & 1715.40 & 3.8 & 4.93 & 16.67 & 70.45 & 451.42 \\
\hline & LDPE $5 \%$ & 1715.40 & 3.8 & 4.61 & 16.4 & 71.89 & 451.42 \\
\hline & LDPE $5.5 \%$ & 2048.80 & 3.8 & 4.1 & 15.95 & 74.31 & 539.16 \\
\hline \multirow{4}{*}{$\mathrm{Pb} 6.5 \%$} & LDPE $0 \%$ & 1440.82 & 2.7 & 4.8 & 17.3 & 72.89 & 533.6 \\
\hline & LDPE $4.5 \%$ & 1715.40 & 2.9 & 4.72 & 16.67 & 73.45 & 591.52 \\
\hline & LDPE $5 \%$ & 1759.80 & 3.7 & 4.39 & 16.4 & 75.17 & 475.62 \\
\hline & LDPE $5.5 \%$ & 2167.40 & 3.8 & 3.94 & 15.95 & 77.12 & 570.37 \\
\hline \multirow[t]{4}{*}{$\mathrm{Pb} 7 \%$} & LDPE $0 \%$ & 1568.21 & 3.6 & 5.99 & 19.84 & 72.03 & 435.6 \\
\hline & LDPE $4.5 \%$ & 1663.50 & 3.7 & 5.8 & 19.68 & 74.23 & 449.59 \\
\hline & LDPE $5 \%$ & 1800.60 & 4.4 & 4.64 & 18.68 & 75.17 & 409.23 \\
\hline & LDPE $5.5 \%$ & 2304.50 & 4.6 & 4.19 & 18.29 & 77.12 & 500.98 \\
\hline
\end{tabular}

Hasil rekapitulasi nilai stabilitas, flow, VIM, VMA, VFA/VFB, dan MQ berikut akan diperjelas menggunakan grafik pada masing-masing untuk memudahkan dalam pembacaan mengenai naik atau turunnya hasil yang sudah diperoleh yang kemudian digunakan untuk menentukan Kadar Aspal Optimum (KAO), sebagaimana dapat dilihat pada Gambar 2.

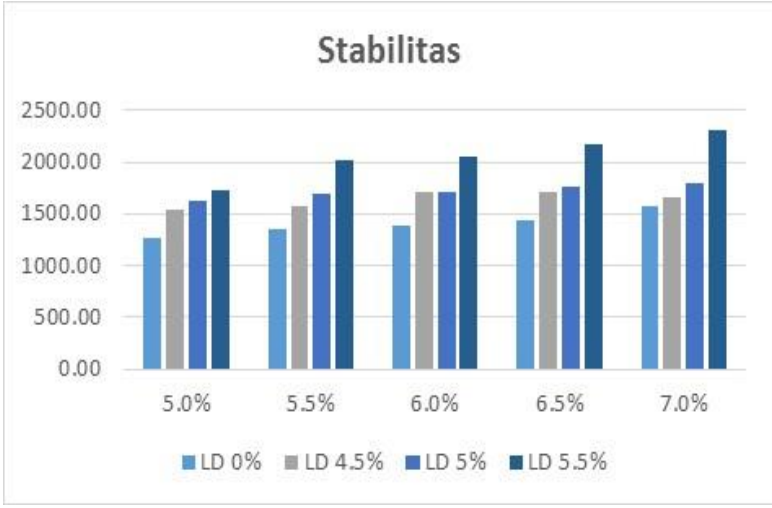

Gambar 2. Rekapitulasi Nilai Stabilitas

Berdasarkan Gambar 2, dapat dilihat bahwa nilai stabilitas semakin tinggi seiring dengan penambahan kadar plastik dan kadar aspal. Didapatkan nilai stabilitas yang tertinggi adalah pada variasi kadar plastik LDPE sebesar 5,5\% dengan variasi kadar aspal $(\mathrm{Pb})$ sebesar $7,0 \%$ yaitu sebesar $2304.50 \mathrm{~kg}$ dari nilai yang diisyaratkan berdasarkan (Spesifikasi Umum Bina Marga, 2018) yaitu minimal $900 \mathrm{~kg}$. Stabilitas Journal of Applied Civil Engineering and Infrastructure (JACEIT) 
mengalami kenaikan yang cukup tinggi. Hal tersebut Nilai VIM berpengaruh terhadap keawetan lapis disebabkan karena plastik mengisi rongga antar butiran perkerasan, semakin tinggi nilai VIM menunjukkan agregat sehingga ronga antar butiran agregat menjadi semakin besar rongga dalam campuran sehingga kecil dan rapat sehingga menyebabkan adanya campuran bersifat pourous. Sedangkan berdasarkan peningkatan daya ikat antara aspal dan agregat. Nilai Gambar 4, dapat dilihat bahwa rekapitulasi hasil stabilitas yang didapat tinggi, sehingga akan pengujian Rongga dalam Campuran (VIM) semakin menyebabkan perkerasan akan menjadi kaku dan mudah rendah nilainya seiring dengan penambahan kadar retak akibat beban lalu lintas. Demikian pula sebaliknya, plastik. Hal ini mengakibatkan campuran menjadi rapat jika nilai stabilitas yang dihasilkan terlalu rendah akan sehingga air dan udara sulit memasuki rongga-rongga menyebabkan mudahnya terjadi deformasi. Berikutnya dalam campuran yang menyebabkan aspal tereduksi. dibawah ini merupakan pemaparan grafik hasil Didapatkan nilai VIM tertinggi pada variasi kadar rekapitulasi pengujian kelelehan (Flow) dapat dilihat plastik LDPE sebesar 0\% atau tanpa kadar plastik pada Gambar 3.

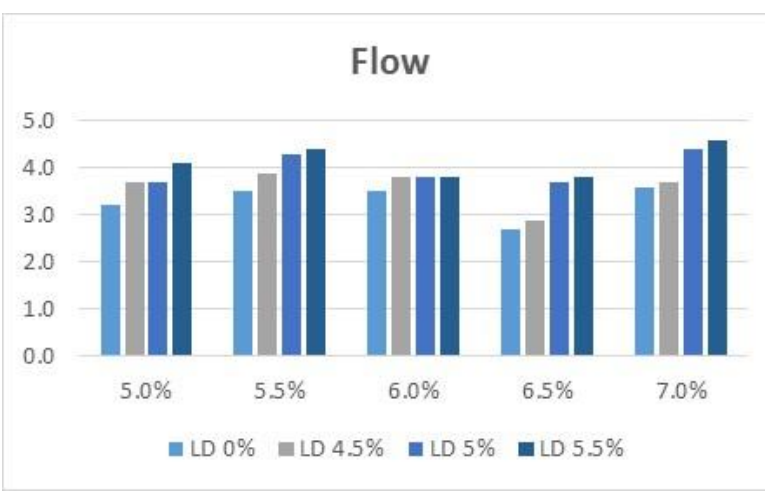

Gambar 3. Rekapitulasi Nilai Kelelehan (Flow)

Berdasarkan Gambar 3, dapat dilihat bahwa hasil pengujian kelelehan (Flow) semakin meningkat seiring dengan penambahan kadar plastik. Nilai stabilitas yang tinggi diikuti oleh nilai flow yang semakin meningkat pula, dikarenakan semakin besar penambahan kadar plastik mengakibatkan mengentalnya campuran aspal plastik, sehingga campuran bersifat elastis. Didapatkan nilai Flow tertinggi pada variasi kadar plastik LDPE sebesar 7,0\% dengan variasi kadar aspal $(\mathrm{Pb})$ sebesar $7,0 \%$ yaitu sebesar 4,6 mm yang artinya nilai tersebut tidak memenuhi persyaratan (Spesifikasi Umum Bina Marga, 2018) yaitu pada rentang 2-4 mm. Selanjutnya merupakan pemaparan grafik hasil rekapitulasi pengujian Void In Mix (VIM) dapat dilihat pada Gambar 4.

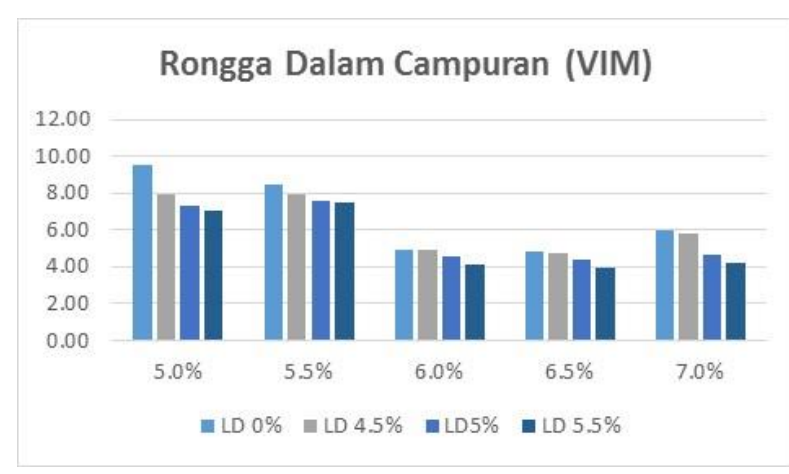
dengan variasi kadar aspal $(\mathrm{Pb})$ sebesar $5,0 \%$ yaitu sebesar 9,54\% yang artinya nilai tersebut tidak memenuhi persyaratan (Spesifikasi Umum Bina Marga, 2018) yaitu pada rentang 3-5\%. Tetapi nilai VIM terendah diperoleh dari kadar plastik LDPE sebesar 5,5\% dengan kadar aspal $(\mathrm{Pb})$ 6,5\% yaitu sebesar 3,94\% dan telah memenuhi (Spesifikasi Umum Bina Marga, 2018). Selanjutnya merupakan pemaparan grafik hasil rekapitulasi pengujian Void Minerale In Aggregate (VMA) dapat dilihat pada Gambar 5.

Hasil rekapitulasi pengujian Rongga dalam Agregat (VMA) sesuai Gambar 5, dapat dilihat bahwa semakin rendah nilainya seiring dengan penambahan kadar plastik. Hal ini disebabkan lapisan plastik telah menyelimuti agregat dan menutup sebagian besar rongga antara butiran. Nilai VMA terendah pada variasi kadar plastik LDPE sebesar 5,5\% dengan variasi kadar aspal $(\mathrm{Pb})$ sebesar 6,0\% dan 6,5\% yaitu sebesar $15,95 \%$ yang artinya nilai tersebut masih memenuhi persyaratan (Spesifikasi Umum Bina Marga, 2018) yaitu minimal $15 \%$. Selanjutnya pemaparan grafik hasil rekapitulasi pengujian Void Filled with Bitumen (VFA/VFB) dapat dilihat pada Gambar 6.

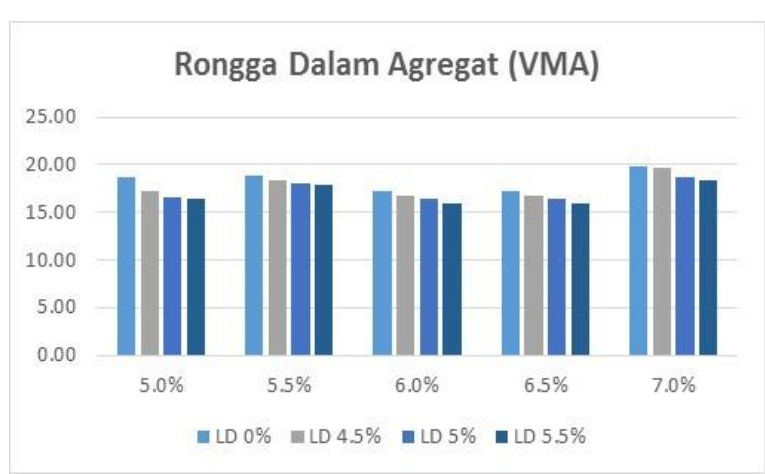

Gambar 5. Rekapitulasi Nilai VMA

Gambar 4. Rekapitulasi Nilai (VIM) 


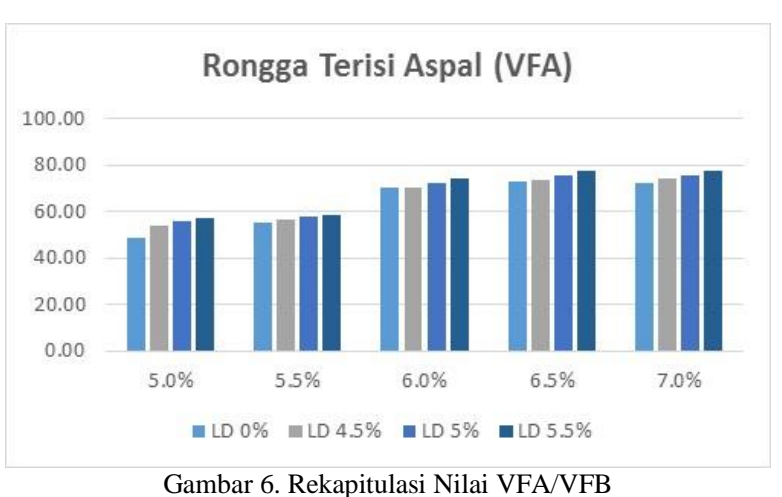

Rekapitulasi hasil pengujian Rongga Terisi Aspal (VFA/VFB) pada Gambar 6, bahwa nilainya meningkat seiring dengan penambahan kadar plastik yang mengakibatkan semakin mengecilnya rongga dalam campuran akibat berat jenis aspal semakin meningkat. Nilai VFA tertinggi pada variasi kadar plastik LDPE sebesar $6,5 \%$ dan $7,0 \%$ yaitu sebesar $77,12 \%$ yang artinya nilai tersebut masih memenuhi persyaratan (Spesifikasi Umum Bina Marga, 2018) yaitu minimal $65 \%$. Selanjutnya pemaparan grafik hasil rekapitulasi pengujian Marshall Quotient (MQ) dapat dilihat pada Gambar 7.

Berdasarkan Gambar 7, dapat dilihat bahwa rekapitulasi hasil pengujian Marshall Quotient (MQ) mengalami kenaikan dan penurunan dikarenakan hasil bagi antara stabilitas dan flow nilainya tidak konstan sehingga nilai MQ mengalami peningkatan dan penurunan. Tetapi semua hasil pengujian masih memenuhi persyaratan (Spesifikasi Umum Bina Marga, 2018) yaitu minimal $250 \mathrm{~kg} / \mathrm{mm}$. MQ dihitung sebagai rasio dari stabilitas terhadap kelelehan yang digunakan sebagai indikator kekakuan campuran. Semakin tinggi nilai MQ suatu Semakin rendah nilai MQ suatu campuran, maka resiko Hal ini diakibatkan karena pada kadar aspal 5\%, 5,5\%, yang memungkinkan adalah retak permukaan dan dan 7,0\% untuk nilai Flow dan VIM didapatkan nilai pergerakan horizontal pada arah perjalanan.

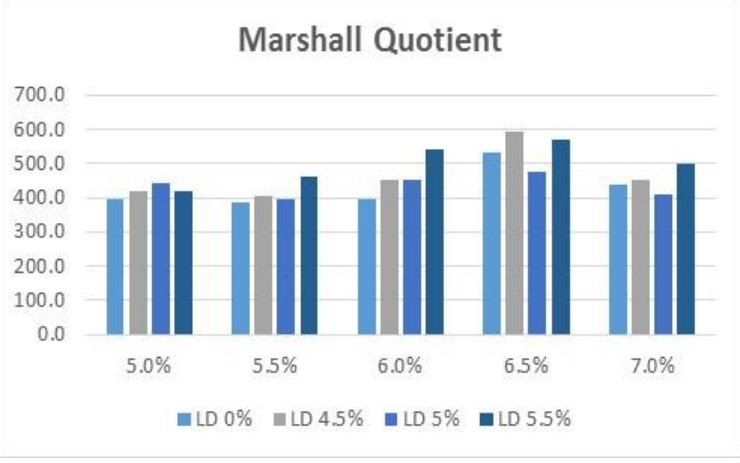

Gambar 7. Rekapitualsi Nilai MQ

\subsection{Penentuan Kadar Aspal Optimum (KAO)}

Kadar Aspal Optimum (KAO) adalah nilai yang harus memenuhi nilai yang disyaratkan berdasarkan (Spesifikasi Umum Bina Marga, 2018) dari rentang variasi yang digunakan yaitu kadar aspal dan kadar plastik yang menggambarkan hubungan dari setiap parameter karakteristik Marshall. Penentuan kadar aspal optimum (KAO) bertujuan untuk mengetahui kadar aspal yang baik atau kadar aspal efektif pada campuran lapis aspal beton. Dari masing-masing grafik hubungan antara parameter pengujian Marshall dengan variasi kadar aspal 5,0\%, 5,5\%, 6,0\%, 6,5\% dan 7,0\% diperoleh nilai kadar aspal optimum pada setiap grafik tersebut. Hasil pengujian Marshall dari penambahan variasi kadar plastik sebesar 4,5\%, 5\%, dan 5,5\% kemudian dihubungkan dengan diagram batang yang dapat dilihat pada Tabel 6 .

Tabel 6. Penentuan Kadar Aspal Optimum (KAO)

\begin{tabular}{|c|c|c|c|c|c|c|c|c|c|c|c|c|c|c|c|c|c|c|c|c|}
\hline Kadar Aspal & \multicolumn{4}{|c|}{$5 \%$} & \multicolumn{4}{|c|}{$5,5 \%$} & \multicolumn{4}{|c|}{$6 \%$} & \multicolumn{4}{|c|}{$6,5 \%$} & \multicolumn{4}{|c|}{$7 \%$} \\
\hline Kadar Plastik & 0 & 4,5 & 5 & 5, & 0 & 4,5 & 5 & 5,5 & 0 & 4,5 & 5 & 5,5 & 0 & 4,5 & 5 & 5,5 & 0 & 4,5 & 5 & 5,5 \\
\hline Stabilitas & & & & & & & & & & & & & & & & & & & & \\
\hline Flow & & & & & & & & & & & & & & & & & & & & \\
\hline VIM & & & & & & & & & & & & & & & & & & & & \\
\hline VMA & & & & & & & & & & & & & & & & & & & & \\
\hline VFA & & & & & & & & & & & & & & & & & & & & \\
\hline MQ & & & & & & & & & & & & & & & & & & & & \\
\hline
\end{tabular}

Berdasarkan Tabel 6, di atas menunjukkan hubungan parameter Marshall dengan kadar aspal pada penggunaan variasi kadar plastik Low Density Polyethylene (LDPE) diperoleh Kadar Aspal Optimum (KAO) yaitu pada kadar aspal (Pb) 6,5\%. Dari hasil tersebut maka dapat diartikan bahwa kadar aspal yang baik digunakan dalam campuran lapis aspal beton dengan menggunakan campuran limbah plastik jenis LDPE sebagai bahan tambah adalah 6,5\% dan hanya pada variasi kadar plastik sebesar 5,5\%. Pemakaian kadar aspal yang masih diperbolehkan adalah pada kadar aspal dibawah kadar aspal optimum yaitu sebesar $6 \%$. yang melebihi dari nilai maksimum yang disyaratkan pada (Spesifikasi Umum Bina Marga, 2018) dan pada kadar aspal 5\% dan 5,5\% didapatkan nilai VFA/VFB dibawah nilai minimum yang disyaratkan.

\section{Kesimpulan}

Dari hasil penelitian yang dilakukan pada campuran Laston AC-WC menggunakan limbah plastik jenis Low Density Polyethylene (LDPE) sebagai bahan tambah diperoleh beberapa kesimpulan antara lain:

1. Adanya penambahan limbah plastik jenis LowDensity Polyethylene (LDPE) pada campuran Laston AC-WC menunjukkan nilai yang memenuhi (Spesifikasi Umum Bina Marga, 2018) dan (Pedoman Perancangan dan Pelaksanaan Campuran Beraspal Panas Menggunakan Limbah Plastik, 2019) pada kadar plastik dan kadar aspal tertentu saja. Diperoleh nilai Kadar Aspal Optimum (KAO) yaitu pada kadar aspal $(\mathrm{Pb})$ sebesar 6,5\% dengan variasi kadar plastik sebesar

Journal of Applied Civil Engineering and Infrastructure (JACEIT) 
5,5\%. Sedangkan untuk pemakaian kadar aspal yang masih diperbolehkan dan memenuhi syarat adalah dibawah kadar aspal optimum yaitu $6 \%$ dengan variasi kadar plastik 4,5\%, 5\%, dan 5,5\%.

2. Semakin besar variasi kadar plastik LDPE yang digunakan dapat mempengaruhi nilai-nilai karakteristik Marshall antara lain peningkatan nilai stabilitas dan flow, nilai rongga terisi aspal atau VFA/VFB, penurunan nilai VIM (Void In Mix) dan VMA (Void Minerale In Aggregate), serta peningkatan dan penurunan nilai MQ (Marshall Quotient).

\section{Ucapan Terimakasih}

Saya ucapkan terimakasih sebesar-besarnya kepada kedua orang tua tercinta yang memberi dukungan moral, dosen pembimbing proyek akhir saya, teknisi laboratorium uji bahan jalan Politeknik Negeri Banyuwangi, serta segenap keluarga besar Jurusan Teknik Sipil Politeknik Negeri Banyuwangi yang telah memfasilitasi penelitian proyek akhir saya.

\section{Daftar Rujukan}

[1] Afriyanto, B., Indriyati, E. W., \& Hardini, P. (2019). Pengaruh Limbah Plastik Low Density Poly Ethylne Terhadap Karakteristik Dasar Aspal. Jurnal Transportasi, Vol.19 59-66.

[2] Balitbang dan BBPJN VIII. (2017). Penerapan Skala Penuh Teknologi Aspal Limbah Plastik. Surabaya: Kementerian PUPR
[3] Kementerian Pekerjaan Umum dan Perumahan Rakyat. (2019). Pedoman Perancangan dan Pelaksanaan Campuran Beraspal Panas Menggunakan Limbah Plastik. Jakarta: Kementerian PUPR.

[4] Rahmawati, A. (2015). Pengaruh Penggunaan Plastik Polyethylene (PE) dan High Density Polyethylene (HDPE) Pada Campuran Lataston-WC Terhadap Karakteristik Marshall. Jurnal Ilmiah Semesta Teknika Vol.18, No.2, 147-159.

[5] Spesifikasi Umum Bina Marga. (2018). Perkerasan Jalan. Surabaya: Kementerian Pekerjaan Umum dan Perumahan Rakyat.

[6] Sustainable Waste Indonesia. (2019, Desember 10). Menuju Indonesia Peduli Sampah. Retrieved from katadata.co.id: https://www.google.com/amp/s/katadata.co.id/amp/infografik/2 019/12/10/menuju-indonesia-peduli-sampah 